\title{
DIFFERENCES IN PHYSIOLOGICAL LOAD OF THE REFEREES WITH CONCIDERATION TO THE PERIOD OF THE BASKETBALL GAME
}

\author{
Tomislav Rupčić ${ }^{1}$, Branka R. Matković ${ }^{1}$, Damir Knjaz ${ }^{1}$, Antonela Nedić ${ }^{1}$, and Siniša Popek ${ }^{1}$ \\ ${ }^{1}$ Faculty of Kinesiology, University of Zagreb, Croatia
}

\begin{abstract}
SUMMARY
The main object of this research was to determine the existance of statistically significant differences in physiological load of the referees concidering the period of the basketball game. The sample of subjects consisted of 31 referees, avarage age of $33.35 \pm 5.17$, from the A referee list of the 1 st Croatian Basketball League in the contest season 2008/2009. The sample of variables consisted of the following: FSM - avarage heart rate; Fsmax - maximum heart rate; E - energy consumption (kcal/ $\mathrm{min})$. Measuring was done during official games of the 1 st Croatian Basketball League in the contest season of 2008/2009. During the game, heart rate was measured with a cardiotachometer (an electronic device for heart rate measurement), produced by POLAR, model RS400 (Finland). Data processing was done using a programme package STATISTICA for Windows, ver 8. Based on the obtained results of univariate variance analysis it was concluded that there are no statistically significant differences in the physiological load between the first and second half - time, as well as between particular quarters of basketball games.
\end{abstract}

Key Words: physical - motor preparation, heart rate, energy consumption.

\section{INTRODUCTION}

In now days basketball is charactarized by high level of activity in all 40 minutes of its duration, which demands a great physical - motor preparation of the players (Matkovic, Matkovic, \& Knjaz, 2005). The past researches of physiological load of the players during a game have pointed out to its high level of intensity (Beam \& Merril, 1994; Hoffman, 2003). The avarage heart rate of the players during a game is at $87 \%$ of the maximum heart rate (Mcdougal, Wegner, \& Green, 1991), or in other words, $75 \%$ of the total game time the players heart rate amounts above $85 \%$, and $15 \%$ of the time amounts above $95 \%$ of the maximum heart rate (McInnes, Carlson, Jones, \& McKenna, 1995).

Both the players and the basketball referees make a component part of every basketball game. The ultimate outcome of most baketball games is decided in the last minutes when the level of physical - motor preparation of the players, their psychological stability and changes in team tactics, greatly influence the final number of technical - tactical errors and errors that result from disregarding the regulations of the game of basketball (Mildenhall \& Holmin, 2004). To make the referees decision as better and more correct as possible, during the game the referee always has to be at the right place and have a quality point of view of the situation. The stated surely demands a great physical preparation of the referees, as well as good visual perception, mental ability, focus of attention, readiness and ability to make fast decisions. Regardless of great importance of the basketball referees, there are very few scientific researches which have delt with them as their main topic. The past researches of the physiological load of the basketball referees have shown a great level of stress to their organism.

The referees are exposed to high level of load while officiating an entire game, especially in the final moments when their activity in the sence of making a larger number of rulings, increases. In other words it can be assumed that physiological load of the referees changes as the game is coming to an end. The main object of this paper was to determine the existence of statistically significant differences in physiological load of the referees concidering a period of the basketball game. 


\section{METHODS}

\section{Sample of subjects}

The sample of subjects consisted of 31 referees avarage age of $33.35 \pm 5.17$, from A referee list of the 1st Croatian Basketball League, season 2008/2009. The avarage hight of the referees was $186.34 \pm 5.40$ $\mathrm{cm}$, and the avarage body mass was $88.04 \pm 7.47 \mathrm{~kg}$. Body mass index varied in the range of 21.80 to 29.80 $\mathrm{kg} / \mathrm{m}^{2}$ with the avarage value of $25.32 \pm 1.60 \mathrm{~kg} / \mathrm{m}^{2}$. For the purpose of this research the level of maximum relative oxygen intake was determined using a standard protocol for estimating functional abilities, done in the Sports - diagnostic Centre of the Faculty of Kinesiology, University of Zagreb, which represents a progressive test of load on a moving carpet with standard inclination of 1,5\% (spiroergometry method). The avarage value of maximum relative oxygen intake was $52.49 \pm 5.80 \mathrm{ml} / \mathrm{kg} / \mathrm{min}$, with the range of results from 43.15 to $65.56 \mathrm{ml} / \mathrm{kg} / \mathrm{min}$. Values of the heart rate in rest have varied in the range of 42 to 86 beats / $\mathrm{min}$ with the avarage value of 66.22 beats/ $\mathrm{min}$.

The referee list was defined by the Croatian $\mathrm{Ba}$ sketball Referee Association, and it is made every year according to the results of officiating in the past regular season.

\section{Sample of variables}

The sample of variables consisted of the following: Fs - avarage heart rate; FSmax - maximum heart rate; $\mathrm{E}$ - energy consumption ( $\mathrm{kcal} / \mathrm{min})$. The physiological load of the referees was followed by heart rate measuring during official basketball games of the 1st Croatian Basketball League in the season 2008/2009. The heart rate during a game was measured with a cardiotachometer (an electronic device for heart rate measuring), produced by POLAR, model RS400 (Finland). Before the beginning of the game, cardiotachometers were put on the referees in the way that an electronic watch (a signal reciever) was placed around the wrist, and a band with the signal transmiter was placed around the chest beneath the official shirt. The electronic devices for heart rate measuring (cardiotachometers) were set in motion just before the beginning of the game. The devices were recordnig the heart rate in an interval of 5 seconds. The game was monitored by official and proffesional person who noted all time intervals during the game using a stop - watch. Every game was also monitored using a video camera which will later allow more quality and more precise analysis of the obtained data. At the end of the game, data from the electronic measuring device were transfered to the computer which enabled further data analysis using an adequate programme aplication (Polar Pro Trainer 5).

\section{Methods of data processing}

Data processing was done using a programme package STATISTICA for Windows, ver 8. The first step in data processing was to calculate central and dispersive paramters for all variables. For each variable the following parameters were calculated: mean $(M)$, standard deviation (SD), minimum value (MIN), maximum value $(M A X)$.

Statistical difference significance between particular parts of the game in variables for estimating the physiological load, were tested using univariate variance analysis (ANOVA).

\section{RESULTS AND DISCUSSION}

The obtained results from Table 1 show that in the first quarter the avarage heart rate amounted 141 \pm 9.88 beats $/ \mathrm{min}$, which is in avarage $75.60 \pm 5.13 \%$ of the maximum heart rate. The avarage value of heart rate moved in the range of 122 to 162 beats/ min, while the highest measured value during first quarter was 187 beats/min. The avarage energy consumption during first quarter was $14.29 \pm 2.24 \mathrm{kcal} /$ $\min$.

In the second quarter the avarage heart rate was $140.25 \pm 9.62$ beats $/ \mathrm{min}$, which is in avarage 75.19 $\pm 4.78 \%$ of the maximum heart rate. The avarage value of heart rate in second quarter moved in the range of 123 to 167 beats/min, while the highest measured value of the heart rate was 186 beats/min. The avarage energy consumption was $14.12 \pm 1.99$ $\mathrm{kcal} / \mathrm{min}$.

During the third quarter the avarage heart rate amounted $139.48 \pm 10.49$ beats $/ \mathrm{min}$, in the range of avarage values of 123 beats/min (the lowest value) to 167 beats/min (the highest value). The obtained avarage heart rate value matches the value of 74.77 $\pm 5.17 \%$ from the calculated maximum heart rate. The highest measured value of the heart rate in third quarter was 188 beats / min, while the avarage energy consumption was $13.94 \pm 2.08 \mathrm{kcal} / \mathrm{min}$.

During the fourth quarter the measured avarage heart rate value amounted $137.80 \pm 9.77$ beats $/ \mathrm{min}$, with the lowest avarage value of 121 beats/min and the highest value of 163 beats/min. The obtained avarage heart rate value in the last quarter matches the value of $73.88 \pm 4.91 \%$ of the maximum heart rate. The highest noted heart rate value in the last quarter was 184 beats / min, while the avarage energy consumption amounted $13.65 \pm 1.76 \mathrm{kcal} / \mathrm{min}$. 
TABLE 1

Basic statistic descriptive parameters of variables for estimating

the physiological load of the referees while officiating basketball games

\begin{tabular}{|c|c|c|c|c|c|}
\hline ID & $\mathrm{MU}$ & $M$ & $S D$ & $M I N$ & $M A X$ \\
\hline HRM1 & beats/min & 141.00 & 9.88 & 122.00 & 162.00 \\
\hline$\% H R \max 1$ & $\%$ & 75.60 & 5.13 & 67.58 & 87.79 \\
\hline $\mathrm{E} M \min 1$ & $\mathrm{kcal}$ & 14.29 & 2.24 & 9.57 & 19.17 \\
\hline HRmin1 & beats/min & 108.87 & 12.03 & 79.00 & 133.00 \\
\hline HRmax1 & beats/min & 164.51 & 10.00 & 146.00 & 187.00 \\
\hline HRM2 & beats/min & 140.25 & 9.62 & 123.00 & 167.00 \\
\hline$\% H R \max 2$ & $\%$ & 75.19 & 4.78 & 67.34 & 85.46 \\
\hline $\mathrm{E} M \min 2$ & kcal & 14.12 & 1.99 & 10.22 & 17.36 \\
\hline $\mathrm{HRmin} 2$ & beats/min & 110.83 & 12.62 & 90.00 & 145.00 \\
\hline HRmax2 & beats/min & 163.67 & 8.65 & 147.00 & 186.00 \\
\hline HRM3 & beats/min & 139.48 & 10.49 & 123.00 & 167.00 \\
\hline$\% \mathrm{HRmax} 3$ & $\%$ & 74.77 & 5.17 & 63.26 & 85.46 \\
\hline $\mathrm{E} M \min 3$ & kcal & 13.94 & 2.08 & 10.29 & 18.00 \\
\hline HRmin 3 & beats/min & 106.32 & 11.87 & 83.00 & 123.00 \\
\hline HRmax3 & beats/min & 162.19 & 10.57 & 141.00 & 188.00 \\
\hline HRM4 & beats/min & 137.80 & 9.77 & 121.00 & 163.00 \\
\hline$\% \mathrm{HRmax} 4$ & $\%$ & 73.88 & 4.91 & 61.73 & 83.72 \\
\hline $\mathrm{E} M \min 4$ & $\mathrm{kcal}$ & 13.65 & 1.76 & 10.43 & 17.45 \\
\hline HRmin4 & beats/min & 109.58 & 12.07 & 90.00 & 139.00 \\
\hline $\mathrm{HRmax} 4$ & beats/min & 161.67 & 9.25 & 142.00 & 184.00 \\
\hline HRM1P & beats/min & 139.93 & 9.41 & 122.00 & 164.00 \\
\hline$\% H R \max 1 \mathrm{P}$ & $\%$ & 75.08 & 4.81 & 68.13 & 86.62 \\
\hline $\mathrm{E} M \min 1 \mathrm{P}$ & $\mathrm{kcal}$ & 14.03 & 2.03 & 9.78 & 17.93 \\
\hline HRM2P & beats/min & 137.87 & 9.86 & 121.00 & 164.00 \\
\hline$\% H R m a x 1 \mathrm{P}$ & $\%$ & 73.92 & 4.97 & 61.73 & 84.30 \\
\hline $\mathrm{E} M \min 1 \mathrm{P}$ & $\mathrm{kcal}$ & 13.66 & 1.87 & 10.34 & 17.61 \\
\hline
\end{tabular}

Legend: ID - Indicator; MU - Mesure unit; $M$ - Sample mean; SD - Standard deviation; $M I N$ - Minimum value; $M A X$ - Maximum value; HRM1,2,3,4 - Avarage heart rate 1,2,3,4 - quarters; \%HRmax1,2,3,4 - Total percentage of maximum heart rate 1,2,3,4 quarters; EMmin1,2,3,4 - Avarage energy consumption per minute 1,2,3,4 quarters (Prosječna energetska potrošnja u minuti 1,2,3,4 četvrtina); HRmin1,2,3,4 - Lowest heart rate value 1,2,3,4 - quarters; HRmax1,2,3,4 Maximum heart rate value 1,2,3,4 - quarters; HRM1P - Avarage heart rate in first half - time; $\% \mathbf{H R m a x} 1 \mathbf{P}$ - Total percentage of maximum heart rate in first half - time; EMmin1P - Avarage energy consumption per minute in first half - time; HRM2P - Avarage heart rate in second half - time; $\mathbf{\% H R m a x} \mathbf{P} \mathbf{P}$ - Total percentage of maximum heart rate in second half - time; $\mathbf{E} M \mathbf{m i n} 2 \mathbf{P}$ - Avarage energy consumption per minute in second half - time.

The avarage heart rate in first half - time (first and second quarter and break between them) amounted $139.93 \pm 9.41$ beats $/ \mathrm{min}$, which matches the value of $75.08 \pm 4.81 \%$ of the maximum heart rate. The avarage maximum heart rate value during first half - time amounted $166.12 \pm 9.73$ beats $/ \mathrm{min}$, and the avarage energy consumption amounted $14.03 \pm$ $2.03 \mathrm{kcal} / \mathrm{min}$.
Similar results were obtained during second half - time (third and fourth quarte and break between them), where the avarage heart rate value amounted $137.87 \pm 9.86$ beats $/ \mathrm{min}$. The obtained avarage heart rate value matches the value of $73.92 \pm 4.97 \%$ of the maximum heart rate. The avarage maximum heart rate value during second half - time amounted $164.16 \pm 9.69$ beats/min and the avarage energy consumption amounted $13.66 \pm 1.87 \mathrm{kcal} / \mathrm{min}$. 
Statistical difference significance between particular parts of the game in variables for estimating the physiological load were tested using the univariate analysis of variance (ANOVA).

\section{TABLE 2}

Testing of differences between first and second half - times of basketball games in variables for estimating the level of physiological load of the referees while officiating - univariate variance analysis (ANOVA).

\begin{tabular}{lrrrrrr}
\hline \multirow{2}{*}{ Variables } & \multicolumn{2}{c}{$1^{\text {st }}$ half-time } & \multicolumn{2}{c}{$2^{\text {nd }}$ half time } & \multirow{2}{*}{$F$} & \multirow{2}{*}{$\boldsymbol{N}$} \\
\cline { 2 - 6 } & \multicolumn{1}{c}{$M$} & $S D$ & \multicolumn{1}{c}{$M$} & $S D$ & & \\
\hline HRM & 139.93 & 9.41 & 137.87 & 9.86 & .710 & .402 \\
\hline HRmax & 166.12 & 9.73 & 164.16 & 9.69 & .636 & .428 \\
\hline E kcal/min & 14.03 & 2.03 & 13.66 & 1.87 & .561 & .456 \\
\hline
\end{tabular}

Legend: $1^{\text {st }}$ half-time, first and second quarter and break between them; $2^{\text {nd }}$ half-time, third and fourth quarter and break between them; HRM - Avarage heart rate; HRmax Maximum heart rate; $\mathbf{E}$ - Energy consumption; $M$ - Sample mena; $S D$ - Standard deviation; $F$ - F-ratio; $p$ - Probability.

\section{TABLE 3}

Testing of differences between first and second half - times of basketball games in variables for estimating the level of physiological load of the referees while officiating - univariate variance analysis (ANOVA).

\begin{tabular}{|c|c|c|c|c|c|c|c|c|c|c|}
\hline \multirow{2}{*}{ Varibale } & \multicolumn{2}{|c|}{$1^{\text {st }}$ quarter } & \multicolumn{2}{|c|}{$2^{\text {nd }}$ quarter } & \multicolumn{2}{|c|}{$3^{\text {rd }}$ quarter } & \multicolumn{2}{|c|}{$4^{\text {th }}$ quarter } & & \multirow[b]{2}{*}{ 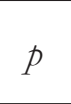 } \\
\hline & $M$ & $S D$ & $M$ & $S D$ & $M$ & $S D$ & $M$ & $S D$ & & \\
\hline & 10 & & 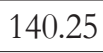 & & 139.48 & 10.49 & 137. & 7 & .586 & .625 \\
\hline & 164.51 & 10.0 & 163. & & 162 & 7 & 16 & 9.25 & .57 & .63 \\
\hline $\mathrm{E} \mathrm{kcal} / \mathrm{min}$ & 14.29 & 2.24 & 14.12 & 1.99 & 13.94 & 2.08 & 13.65 & 1.76 & .569 & .636 \\
\hline
\end{tabular}

Legend: HRmax - Maximum heart rate; E - Energy consumption; $M$ - Sample mena; $S D$

- Standard deviation; $F$ - F-ratio; $p$ - Probability.

Based on the obtained data of univariate variance analysis (Table 2) it is concluded that there is no statistically significant shift between first (first and second quarter and break between them) and second half time (third and fourth quarter and break between them) of the basketball game in the variables for estimating the level of physiological load: FS - avarage heart rate $(F=.710, p=.402)$; Fsmax - maximum heart rate $(F=.636, p=.428) ; \mathrm{E}-$ energy consumption $(F=.561, p=.456)$; with the level of significance of .05 .

Therefore, in second half - time the values of energy consumption, avarage heart rate and maximum heart rate are somewhat lower, however the differences are not statistically significant at the level of significance of .05 .

Although, the values of central parameters of avarage and maximum heart rate as well as the energy consumption, are gradually reduced as the game is coming to an end. From the obtained data of univariate variance analysis (Table 3) it can be seen that there are no statisically significant differences between particular periods (quarters) in the level of physiological load of the referees during the game. In other words, the obtained statistic results show that variability between the groups is not significantly bigger than variability within the groups at the level of significance of .05 .

Based on the obtained data of the relative maximum oxygen intake it can be concluded that the referees have a well developed aerobic capacity (Leicht, 2007), similar to professional basketball players (Castagna et al., 2009) and the referees from other team sports (Casajus \& Castagna, 2007; Castagna \& D'Ottavio, 2001; Krustup \& Bangsbo, 2001).

The obtained data are pointing out to a high physiological load which doesn't statistically significant change at well prepared referees concidering the period of the game.

In view of proven high physiological load which results from dynamics of the game of basketball, it can be assumed that physical - motor preparation of the referees is of high importance to their quality of officiating. 
Research results fold over with results obtained in other researches of physiological load of the referees during basketball games. Thus, Leicht in his researches noted the vales of heart rate during a game between 130 and 150 beats/min, or $73-79 \%$ of the maximum heart rate. More than $63 \%$ of the time interval the referees spent in an intensity load higher than $70 \%$ of the maximum heart rate. Based on these results it was concluded that the referees are exposed to high level activities during an entire game (Leicht, 2004, 2008). In the research of Rupcic (2010), based on the obtained heart rate values during officiating basketball games and heart rate values at anaerobic threshold, it was concluded that basketball referees spent $50 \%$ of an overall game time in the zones of high aerobic load. Taking into consideration only the quarters, without the breaks between them, that percentage amounts up to $60 \%$. Considering the time spent in particular intensity zone, and also the energy consumption values, it was concluded that the referees, while officiating a game, are exposed to high physiological load (Ibid).

Similar results were also obtained in other team sports such as football and rugby (Barbero Alvarez, Boullosa, Nakamura, Andrin, \& Castagna, 2012; Catterall, Reilly, Atkinson, \& Coldwells, 1993; D'Ottavio \& Castagna, 2001; Martin, Tolfrey, Smith, \& Jones, 2005). Although significant differences in avarage heart rate values between first and second half - time weren't determined, there are however certain variations. That's how D'ottavio and Castagna (2001) noticed that cardiovascular system load of the italian Series A referees, was lower in first 15 minutes of the first half - time, while Helsen and Bultynck (2004) noticed significant variations of heart rate during important games. The lowest heart rates were measured in first 15 minutes of both half - times, and the highest in last 15 minutes also in both half - times. This increase at the end of half - times, authors link to an increased effort of the referees in keeping up with the game rate. There are many other factors which influence the change in heart rate besides the intensity of the game, such as dehydration, thermal stress, psychological stress, high intensity activities.

\section{CONCLUSION}

With concideration to determined high physiological load of the referees during an entire basketball game, it is logical to conclude that the referees must have optimally developed physical - motor preparation. Otherwise they wouldn't be able to follow dynamic movement of the players and accordingly complexed game situations, which in the end would result in bad, not precise enough estimation of game situations. All of the stated would directly result to the outcome of the game itself. That observation comes out of the fact that bad physical - motor preparation influences on a faster show of weariness, which will ultimately result in considerable reduction of concentration in the given moment, which implies a very short time interval when it is necessary to form a judgement about a specific game situation. Of course, good physical - motor preparation of the referees is only one of the prerequisites for quality officiating. It can be assumed that experience in officiating, theoretical knowledge and feeling for the game are certainly additional factors which influence the quality of every referee.

\section{REFERENCES}

Barbero Alvarez, J. C., Boullosa, D. A., Nakamura, F. Y., Andrin, G., \& Castagna, C. (2012). Physical and physiological demands on field and assistant soccer referees during America's cup. Journal of Strength and Conditioning Research, 26(5):

1383-1388. PMid: 22395268

Beam, W. C., \& Merrill, T. L. (1994). Analysis of heart rates recorded during female collegiate basketball. Medicine \& Science in Sports \& Exercise, 26, S66. doi: 10.1249/00005768-19940500100373

Casajus, J. A., \& Castagna, C. (2007). Aerobic fitness and field test performance in elite Spanish soccer of referees different ages. Journal of Science and Medicine in Sport, 10(6), 382-389. doi: 10.1016/j.jsams.2006.08.004; PMid: 17116419

Castagna, C., Chaouachi, A., Rampinini, E., Chamari, K., \& Impellizzeri, F. (2009). Aerobic and explosive power performance of elite Italian regional-level basketball players. Journal of Strength and Conditioning Research, 23(7), 1982-1987. doi: 10.1519/ JSC.0b013e3181b7f941; PMid: 19855321

Castagna, C., \& D'Ottavio, S. (2001). Effect of maximal aerobic power on match performance in elite soccer referees. Journal of Strength and Conditioning Research, 15(4), 420-425. doi: 10.1519/1533-4287(2001)015<0420:EOMAPO >2.0.CO;2; doi: 10.1519/00124278-20011100000004; PMid: 11726251

Catterall, C., Reilly, T., Atkinson, G., \& Coldwells, A. (1993). Analysis of the work rates and heart rates of association football referees. British 
Journal of Sports Medicine, 27(3), 193-196. doi: 10.1136/bjsm.27.3.193; PMid: 8242278; PMCid: 1332186

D'Ottavio, S., \&Castagna, C. (2001). Physiological load imposed on elite soccer referees during actual match play. Journal of Sports Medicine and Physical Fitness, 41(1), 27-32. PMid: 11405189

Helsen, W., \& Bultynck, J. B. (2004). Physical and perceptual-cognitive demands of top-class refereeing in association football. Journal of Sports Sciences, 22, 179-189. doi: 10.1080/02640410310001641502; PMid: 14998096

Hoffman, J. R. (2003). Physiology of basketball. In D. R. Mckeag (Ed.), Basketball (pp. 12-25). Malden, Massachusetts: Blackwell Science Ltd.

Krustrup, P., \& Bangsbo, J. (2001). Physiological demands of top-class soccer refereeing in relation to physical capacity: effect of intense intermittent exercise training. Journal of Sports Sciences, 19, 881-891. doi: 10.1080/ 026404101753113831; PMid: 11695510

Leicht, A. S. (2004). Cardiovascular stress on an elite basketball referee during natiolnal competition. British Journal of Sports Medicine, 38(4), E10. doi: 0.1136/bjsm.2003.006908; PMid: 15273203; PMCid: 1724848

Leicht, A. S. (2007). Aerobic power and anthropometric characteristics of elite basketball referees. Journal of Sports Medicine and Physical Fitness, 47(1), 46-50. PMid: 17369797

Leicht, A. S. (2008). Physiological demands of basketball refereeing during international competition. Journal of Science and Medicine in Sport, 11(3), 357-360. doi: 10.1016/j. jsams.2007.05.006; PMid: 17714989
Martin, J. A., Tolfrey, K., Smith, N. C., \& Jones, A. M. (2005). Heart rate responses of rugby referees in the English Premiership. Journal of Human Movement Studies, 48(3), 211-225.

Matković, B. R., \& Matković, B. (2010). Funkcionalne i motoričke karakteristike košarkaša i košarkašica [Functional and motor characteristics of men and women basketball players]. In B. Matković (Ed.), Antropološka analiza košarkaške igre (pp. 107-121). Zagreb, Croatia: Kineziološki fakultet Sveučilišta u Zagrebu, Hrvatski košarkaški savez.

Matković, B. R., Matković, B., \& Knjaz, D. (2005). Fiziologija košarkaške igre [Physiology of basketball game]. Hrvatski športskomedicinski vjesnik, 20(2), 113-124.

McDougal, J., Wegner, H., \& Grenn, H. (1991). Physiological testing oft the high performance athlete. Champaign, IL: Human Kinetics.

McInnes, S. E., Carlson, J. S., Jones, C. J., \& McMenna, M. J. (1995). The physiological load imposed on basketball players during competition. Journal of Sport Science, 13, 386-397. org: 10.1080/02640419508732254; PMid: 8558625

Mildenhall, B., \& Holmin, J. (2004). Do You have the right level of tension? Fiba Assist Magazine, 43-44.

Rupčić, T. (2010). Fiziološko opterécenje sudaca tijekom košarkaške utakmice [Physiological workload of referee during a basketball game]. (Unpublished doctoral dissertation). University of Zagreb, Faculty of Kineziology.

Rupčić, T., Matković, B., \& Knjaz, D. (2010). Antropološki profil košarkaških sudaca [Anthropological profile of basketball referees]. Hrvatski Śportskomedicinski Vjesnike, 25, 16-22.

Received: December 25, 2011 Revision received: March 29, 2012 Accepted: May 15, 2012

Correspodence to: TomislavRupčić, $\mathrm{PhD}$ Faculty of Kinesiology University of Zagreb Horvacanski zavoj 15 10000 Zagreb, Croatia

E-mail: tomislav.rupcic@kif.hr Phone: 0038598 990-6018 